\title{
Structural Adjustment and Poverty: The Case of Pakistan
}

\author{
TILAT ANWAR
}

\begin{abstract}
Despite the external shocks in the 1980s, the economy continued to grow at a respectable rate. However, increasing internal and external imbalances caused an economic crisis in 1988 and lead to an implementation of a medium term structural adjustment programme within the framework of the IMF and the World Bank. Neither theory nor existing evidence gives a conclusive verdict about the effects of adjustment policies on poverty. Hence, the paper examines the actual changes in absolute poverty during the period of adjustment. The actual changes in the distribution have been examined from two comparable household income and expenditure surveys (HIES) for 1987-88 and 1990-91, spanning the period of adjustment. Evidence suggests that the stylised facts of structural adjustment policies are consistent with actual changes in the absolute poverty. The first order stochastic dominance test suggests that not only the absolute poverty incidence but also the intensity and severity of poverty increased significantly by all poverty lines and poverty measures over the period of adjustment. Structural adjustment created new poor in urban areas amongst the low income groups (mainly Clerical and Sales workers) whose real wages were eroded over the period. Poverty also increased unambiguously among self-employed (smallholders in the informal sector) and unemployed who seems to have been affected adversely by the overall economic contraction. Though, the government has the priority to achieve the fiscal balance, it should seek to ameliorate the most distressing cost arising in the short run. Excessive reliance on demand management in scale or speed is counter-productive for adjustment. Adjustment strategies need to account for the trade-off between shortterm gains and long-term benefits foregone.
\end{abstract}

\section{INTRODUCTION}

Though GDP grew at a respectable rate, the government resource position deteriorated during the late 1980s mainly due to weak government revenue collection and rising expenditure. The government prompted to implement a medium term structural adjustment programme within the framework of the IMF and the World Bank in 1988 [Government of Pakistan (1993)]. The structural adjustment programme was designed to remove the structural rigidities and distortions in the incentive system in order to restore the macroeconomic balances to sustainable levels by the end of fiscal year 1990-91. The objectives of the adjustment

Tilat Anwar is Lecturer in Economics at the Allama Iqbal Open University, Islamabad.

Author's Note: I wish to thank Emeritus Professor (Sir) Hans Singer, Institute of Development Studies, and Mr Andy Newell, University of Sussex, for their critical comments on an earlier draft of this paper. 
programme were to be achieved through policy reforms in the trade, industry, agriculture, financial and energy sector as well as in fiscal area.

It has been argued that the adjustment policy reforms sought excessive reduction in aggregate demand resulting in an unwarranted contraction of output and employment as well as living standard of poor. How do these policy reforms affect poverty among household? How did poor households fare in Pakistan during the period of adjustment? This paper answers the above questions. The paper is organised as follows: Section 2 discusses the orthodox model which has been used by the international financial institution to design the structural adjustment programme. Section 3 assesses the impact of expenditure reducing policies on poverty in Pakistan. The section also examines the impact of liberalisation and pricing policies on poor households. Section 4 examines the changes in absolute poverty during the period of adjustment. Finally, Section 5 draws some conclusions from the analysis.

\section{THE ORTHODOX MODEL}

Since many developing countries have experienced internal and external imbalances during the 1980's, financial assistance has been asked from the IMF and the World Bank to restore the internal and external disequilibrium which they have provided by placing conditionalities in the form of policy prescription. Structural adjustment programmes are designed to change the structure of the economy so as to improve the balance of current account and budget deficit over the medium term. The conceptual framework for the structural adjustment programme designed by IMF/World Bank argues that a depreciation of the real exchange rate $\left(P_{t} / P_{n}\right)^{1}$ generate price incentives which favour the tradable relative to the non-tradable goods sector. The labour market is expected to play a central allocative role. IMF requires wage restraint in the Fund-supported stabilisation programmes in many developing countries. Real wage flexibility is considered central to the successful implementation of the stabilisation policies. It is argued that for stabilisation to obtain its desired results, real wages must fall where they have been historically high [IMF (1986)]. As is the case with prices in other markets the emphasis has been on getting the price of labour right. This is perceived essential for the stimulation of employment growth, reallocation of resources from nontradables to tradables production and promotion of exports. Hence, the IMF stabilisation measures usually working in a contractionary direction tend to come first and have immediate effect. The World Bank structural adjustment measures and the longer-term structural adjustment finance take a much longer time to be effective. This approach is based on the orthodox assumption of a perfect labour market which ignores a number of important conflicts arising from macroeconomic

\footnotetext{
${ }^{1}\left(P_{t} / P_{n}\right)$ is one definition of the real exchange rate, See World Bank (1990) and Demery and Addison (1993).
} 
policy. The nontradable activities contract faster than the expansion in the tradable activities especially, if later needs investment in the equipment and infrastructure in building a new establishment. Hence, the approach is likely to cause an unwarranted contraction of output and employment as well as living standard of poor.

Since the various policy reforms are implemented sequentially as well as simultaneously, structural adjustment programme is defined as a set of policies which combines short-term stabilisation measures and longer-term adjustment measures. These policy reforms may affect poverty and income distribution among households through numerous and complex channels. ${ }^{2}$ A clear-cut conclusion regarding the effects on poverty is not possible. The inconclusiveness of the effect of structural adjustment on income distribution may be attributed to the following factors. ${ }^{3}$ First, any single policy may affect income distribution in a number of ways not all working in the same direction. Second, various policy instruments which together constitute a structural adjustment programme can have conflicting effects, so that it may be difficult to be precise about the net effect of the programme. Hence, the paper discusses the most likely distributional impact of structural adjustment policies in the subsequent sections.

\section{MACROECONOMIC CHANGES DURING THE ADJUSTMENT PROGRAMME}

The GDP growth rates as well as sectoral growth rates fell slightly over the period of adjustment. However, some exogenous shocks, e.g. a flood in August 1988, a deterioration in terms of trade, and the Gulf war in 1990-91 affected the targets of the programme. Hence, some slippages occurred in the monetary, fiscal and financial reforms. Table 1 presents data on some important macroeconomic variables. In 1988-89, inflation accelerated to 10.4 percent because of the earlier rise of liquidity in the economy and constrained production growth. Reflecting the tight monetary policy in 1988-89, inflation decelerated to 6.0 percent in 1989-90. However, the government was not able to contain liquidity growth in 1989-90 as compared to the previous fiscal year. Prices responded to this expansion and inflation was over 10 percent in 1990-91. This rising trend was strengthened by costpush factors such as increases in administered price for fertiliser, depreciation of rupee against US dollar ${ }^{4}$ and subsequent increases in price for petroleum products due to the Gulf war in early 1990. Hence, inflation rose to 12.70 percent in 199091[Government of Pakistan (1993)].

\footnotetext{
${ }^{2}$ For a good discussion of such channels, see IMF (1986); World Bank (1990).

${ }^{3}$ See Demery and Addison (1993); Kanbur (1987); IMF (1986) and World Bank (1990).

${ }^{4}$ The cumulative depreciation of Pak rupee vis-à-vis US dollar between 1987-88 to 1990-91 was 27.45 percent.
} 


\section{Expenditure-reducing Measures}

To reduce the budget deficit, the government took several measures such as wage restraint, freezing employment and limiting discretionary grants to provinces. The budget deficit was reduced from 8.5 percent of GDP in $1987-88$ to 6.5 percent in the first two years of the programme. However, a sharp fall in public revenues ${ }^{5}$ in 1990-91 resulted in an increase in the fiscal deficit to 8.7 percent of GDP in 199091. On the expenditure side, the government made progress in reduction of overall expenditure between 1989-90 and 1990-91. The government reduced expenditure on social services mainly on education and health services over the period of adjustment. As a result the share of social services expenditures as percentage of GNP which was already low compared to other low income countries, ${ }^{6}$ declined from 3.4 percent in 1987-88 to 2.8 percent in 1990-91. Reduced expenditure on social services may not only adversely affect the education and health status of poor but also affect the earning capacity of most vulnerable groups by lowering the demand for labour in the short run. In addition, the government also reduced development expenditure as percentage of GNP from 6.8 percent in 1987-88 to 6.5 percent in 1990-91. Cut in development expenditure may not only reduce employment opportunities for the poor (as daily unskilled labour) in the short run but may also adversely affect the quality and quantity of services provided to the poor through social and economic infrastructure in the long run.

The government sought to restrain aggregate demand not only by granting wage increases below the inflation rate but also by freezing the employment in the public sector. Thus, the wage bill has been reduced by reducing employment and restricting wage increases over the period of adjustment. Over the period of adjustment, employment cost fell from 35.4 percent to 32.3 percent of public expenditure. Kemal (1993) argued that the structural adjustment programme, resulting in a complete ban on recruitment to government jobs, has reduced government employment. The IMF requires restrictions both on wage increases and on government employment. This is considered essential for the stimulation of employment growth, reallocation of resources from nontradables to tradables production and promotion of exports. This approach is based on the orthodox assumption of a perfect labour market which ignores a number of important conflicts arising from macroeconomic policy. As is the case elsewhere, nontradable activities

${ }^{5}$ Public revenues as a percentage of GDP declined as revenues from custom duties declined from 5.9 to 4.9 percent of GDP. Profit made by Post Office and Telegraphs and Telecommunications also fell. Altogether this amounted to a decline in revenue of 1.8 percent of GDP. See Kemal (1993).

${ }^{6}$ The low investment in human capital is closely reflected in the poor social sector indicators. In 1987/88, the infant mortality rate was about 105 per thousand, compared with an average of 98 per thousand for other low income countries; primary enrolment was 41 percent compared to 76 percent; and adult illiteracy was estimated at 74 percent compared to 51 percent. These indicators have also deteriorated over the period of adjustment. For more details, see Anwar (1992). 
contract faster than the expansion in the tradable activities especially, if later needs investment in the equipment and infrastructure in building a new establishment. Hence, unemployment rose from 3.1 percent to 3.6 percent over the period of adjustment.

Bilquees (1992) argued that the government wage policy contributed to a decline in real wages in the public sector over the period. While the lowest grade earned an increase of 3.66 percent in salary, the middle and higher grades experienced a real wage cut of 5.16 percent and 12.75 percent, respectively over the three year period [Bilquees (1992)]. While the lowest grade employees were already in a significant proportion among the poor, erosion of real wages of middle grade employees (especially clerical workers) is likely to create some new poor over the period of adjustment.

In addition, restraining employment in the public sector resulted in increased available labour supply to the other sectors in the economy. These trends were heightened the pressure in labour market in the other sectors. As a result the real wages in agriculture and manufacturing sectors declined in the first year of adjustment (see Table 1). The real wages revived in the second year of adjustment, however, they again declined in the final year of adjustment. Thus, the government wage and employment restraint policy seem to have deteriorated the functional income distribution. The share of wages in national income declined from 32.3 percent in 1987-88 to 30 percent in 1990-91 (see Table 1). These changes seem to have harsh consequences for poor households over the period of adjustment.

In addition, lowering the real wages contracted the aggregate demand in the goods market, thus reduced the labour income and depressed the demand for consumer goods. As a result of these factors, the real private per capita consumption expenditure fell by 5.6 percent over the three years of adjustment [Government of Pakistan (1993)]. The decline in real private per capita consumption expenditure gives a clear indication of possible worsening the welfare and living conditions of the poor and vulnerable groups of population over the period. Thus, it is likely that the evidence from household surveys (discussed below) would also show a decline in the living conditions of the poor over the period.

\section{Revenue Measures}

To raise the revenue, the government introduced a General Sales tax in November 1990. Taxes on goods and services are considered to be more regressive than income taxes, primarily because consumption forms a larger proportion of the income of lower income groups. The demand for necessities such as food products are considered to be inelastic. The tax increases on necessities are likely to raise inequality in consumption. Kemal (1992) estimated that incidence of General Sales tax was the most for the lowest income groups, while for the highest income group 
Table 1

Macroeconomic Indicators, $1980-81$ to $1990-91$.

\begin{tabular}{|c|c|c|c|c|c|c|c|c|c|c|c|}
\hline & $80 / 81$ & $81 / 82$ & $82 / 83$ & $83 / 84$ & $84 / 85$ & $85 / 86$ & $86 / 87$ & $87 / 88$ & $88 / 89$ & $89 / 90$ & $90 / 91$ \\
\hline $\begin{array}{l}\text { GDP growth } \\
\text { (at factor cost) } \\
\text { Consumer Price }\end{array}$ & 6.40 & 7.56 & 6.79 & 3.97 & 8.71 & 6.36 & 5.81 & 6.44 & 4.81 & 4.63 & 5.58 \\
\hline $\begin{array}{l}\text { Index (\% Growth) } \\
\text { As \% of GDP }\end{array}$ & 13.85 & 11.10 & 4.70 & 7.30 & 5.70 & 4.40 & 3.60 & 6.30 & 10.40 & 6.00 & 12.70 \\
\hline Public Expenditure & 22.9 & 21.9 & 23.9 & 23.8 & 24.7 & 26.1 & 26.6 & 26.7 & 26.1 & 25.7 & 25.5 \\
\hline Public Revenue & 17.6 & 16.6 & 16.8 & 17.8 & 17.0 & 18.1 & 18.4 & 18.2 & 18.7 & 19.2 & 16.8 \\
\hline Budget Deficit & 5.3 & 5.3 & 7.0 & 6.0 & 7.8 & 8.1 & 8.2 & 8.5 & 7.4 & 6.5 & 8.7 \\
\hline $\begin{array}{l}\text { Expenditure on social } \\
\text { services (as \% of GNP) }\end{array}$ & - & 2.0 & 2.1 & 2.2 & 2.5 & 3.0 & 3.1 & 3.4 & 3.4 & 3.1 & 2.8 \\
\hline Employment cost & & & & & & & & & & & \\
\hline $\begin{array}{l}\text { As \% of public } \\
\text { expenditure }\end{array}$ & 41.8 & 40.2 & 37.9 & 38.1 & 36.8 & 36.5 & 36.1 & 35.4 & 35.3 & 34.5 & 32.3 \\
\hline As \% of GDP & 5.7 & 5.5 & 6.0 & 6.5 & 6.5 & 6.7 & 7.3 & 7.8 & 7.9 & 7.5 & 7.0 \\
\hline $\begin{array}{l}\text { Wage Share in National } \\
\text { Income (\%) } \\
\text { Real Wages }\end{array}$ & 30.2 & 30.2 & 30.1 & 30.7 & 30.1 & 31.8 & 33.0 & 32.3 & 30.0 & 30.2 & 30.0 \\
\hline$\overline{\text { Agriculture }}$ & 100 & 132 & 129 & 124 & 125 & 131 & 134 & 135 & 131 & 135 & 134 \\
\hline Manufacturing & 100 & 95 & 102 & 101 & 91 & 108 & 121 & 124 & 114 & 123 & 121 \\
\hline Unemployment rate & 3.72 & 3.81 & 3.91 & 3.82 & 3.72 & 3.66 & 3.05 & 3.1 & 3.1 & 3.1 & $3.6^{+}$ \\
\hline
\end{tabular}

Sources: Government of Pakistan (1993), Economic Survey. Federal Bureau of Statistics (1980 to 1991), Monthly Statistical Bulletin.

+Labour Force Survey, 1990-91 employing new definition of unemployment reports 6.3\% unemployment rate for 1990-91. Contrary to the old one, the new definition excludes all unpaid family helpers from employment. ILO (1994), International Labour Statistics. 
tax incidence declined over the period. Hence, the introduction of General Sales tax appears to have had a negative effect on the real income of poor over the period.

\section{Pricing Policies}

To contain the subsidies, the price of wheat was increased by 9.5 percent in April 1989, the average price of fertilisers by 9.5 percent in September 1989 and edible oil prices by 22 percent [Government of Pakistan (1993)]. The government also significantly reduced consumer subsidies by abolishing its wheat flour rationing and sugar ration shop. To pass on the increases in world prices to consumers, the government increased the domestic price of petroleum by 42 percent in November 1990. Power prices have also been increased by 13 percent in 1989-90 and by 8 percent in 1990-91. To reduce the gap between gas and fuel oil prices, the natural gas prices to households increased by 37 percent in 1988-89 [Government of Pakistan (1993)].

The direct impact of the increases in the prices of petroleum, power and energy on poor household seems to have been relatively small. With fuel and power combined accounting for 7.39 percent of the poverty line, ${ }^{7}$ the price increases for petroleum and power has implied only a modest direct impact on the poor consumer. However, higher energy costs feed into prices of consumption goods. Moreover, the cost of public transport may increase because of higher fuel costs and thus affect the poor adversely. On the other hand, food items combined accounting for nearly 55 percent, the price increases for the food commodities will have a greater impact on the real income of the poor segments of population.

\section{Import Liberalisation}

In 1989-90 fiscal year, the government started the first stage of a comprehensive medium term programme to liberalise the trade regime. The government gradually replaced the bans and other non-tariff barriers with tariffs and lowered the maximum tariff from 225 percent to 100 percent by July 1990 [Government of Pakistan (1993)]. The initial impact of liberalisation on consumer prices came through the domestic supply response related to the increased availability of imported inputs and consumer goods. Ultimately, liberalisation is expected to generate more import competition for such goods, thus may depress consumer prices. However, the reduction in tariffs is likely to cause domestic demand to shift from import-competing industries toward imports as their prices started to fall. This shift in demand may result in some reduction in domestic production as well as in employment in the previously protected industries, leading to an overall contraction in economic activity, since labour is not likely to be immediately absorbed in other industries. Since most of the industrial activities are based in urban areas, the liberalisation is likely to exacerbate urban unemployment

\footnotetext{
${ }^{7} \mathrm{~A}$ decomposition of the poverty line into various food and non-food components has been done by Anwar (1996).
} 
over the period. Hence, the combined effect of public expenditure reduction (discussed above) and liberalisation resulted in an increase in the urban unemployment from 4.58 percent in 1987-88 to 8.19 percent $^{8}$ in 1990-91. Hence, the import liberalisation seems to have affected the low-income urban population on the sources of income side through its contractionary effects.

\section{CHANGES IN ABSOLUTE POVERTY}

The above discussion shows that structural adjustment programme is likely to increase the poverty in the short run. On the other hand, neither theory nor existing evidence gives a conclusive verdict about the effects of structural adjustment programme on poverty. ${ }^{9}$ Hence, the actual changes in absolute poverty have been examined over the period of adjustment. To examine the actual changes in the distribution two comparable household income and expenditure surveys (HIES) for 1987-88 and 1990-91, spanning the period of adjustment have been used.

To define the poverty, the view has been taken that poor nutrition plays a central part in the conception of poverty. In addition, the view has also been taken that nobody can live by food alone. Hence, poverty is defined in terms of deprivation of a minimum bundle for the maintenance of basic necessities of human life such as food, clothing and housing. The minimum bundle is defined in subsistence terms for food and non-food human requirements. For food requirements, the approach is based on the recommended daily calorie intake for an individual. Calorie expenditure function has been estimated by OLS to derive the food poverty lines. ${ }^{10}$ For non food human requirement, a socially acceptable minimum bundle has been derived by computing the average non-food expenditure amongst those identified as being poor according to the food poverty criterion alone. HIES micro data has been used to examine the changes in poverty between 1987-88 and 1990-91. In view of the variability of income of the poor over time especially in underdeveloped rural economies depending on rain-fed agriculture, current consumption expenditure (including imputed) is used for the measurement of living standard and welfare. Table 2 reports estimates of poverty in Pakistan for FGT class of poverty measures. ${ }^{11}$ All three FGT measures indicate an increase in poverty in Pakistan

${ }^{8}$ According to the new definition of unemployment. Section 2.

${ }^{9}$ See Demery and Addison (1993); Kanbur (1987); IMF (1986) and World Bank (1990). Also see

${ }^{10}$ See Anwar (1996) for derivation of poverty lines by this method.

${ }^{11}$ Foster, Greer and Thorbecke (1984) introduced the class of poverty measures, $P_{\alpha}$ which does not only reflect the severity of poverty but also satisfy the axiom of decomposability additively. Thus

$$
P_{\alpha}=\frac{1}{n} \sum_{i=1}^{q}\left[\left(z-y_{i}\right) / z\right]^{\alpha}
$$

This measure has clear advantages for some purposes, such as comparing policies which are aiming to reach the poorest. Note that if $\alpha=0$, the FGT index, $P_{\alpha}=$ Headcount measure, if $\alpha=1, P_{\alpha}=$ Poverty gap index and if $\alpha=2, P_{\alpha}$ is the mean of squared proportionate poverty gaps and indicates greater severity of poverty among the poorest. 
Table 2

Changes in Poverty Incidence, Intensity and Severity between 1987-88 and 1990-91 in Pakistan using province-region Specific Poverty Lines.

\begin{tabular}{|c|c|c|c|c|c|c|c|c|c|}
\hline Region & $\begin{array}{l}\text { Head-Count } \\
\qquad \begin{array}{c}\left(\mathrm{P}_{0}\right) \\
(\alpha=0) \\
1987-88\end{array}\end{array}$ & $\begin{array}{l}\text { Head-Count } \\
\qquad \begin{array}{c}\left(\mathrm{P}_{0}\right) \\
(\alpha=0) \\
1990-91\end{array}\end{array}$ & $\begin{array}{l}\eta \text {-test } \\
\text { for } P_{0}\end{array}$ & $\begin{array}{c}\text { Poverty Gap } \\
\qquad\left(\mathrm{P}_{1}\right) \\
(\alpha=1) \\
1987-88\end{array}$ & $\begin{array}{c}\text { Poverty Gap } \\
\qquad\left(\mathrm{P}_{1}\right) \\
(\alpha=1) \\
1990-91\end{array}$ & $\begin{array}{l}\eta \text {-test } \\
\text { for } P_{1}\end{array}$ & $\begin{array}{c}\text { FGT Index } \\
\qquad \begin{array}{c}\left(\mathrm{P}_{2}\right) \\
(\alpha=2) \\
1987-88\end{array}\end{array}$ & $\begin{array}{c}\text { FGT Index } \\
\left(\mathrm{P}_{2}\right) \\
(\alpha=2) \\
1990-91\end{array}$ & $\begin{array}{l}\text { h-test } \\
\text { for } P_{2}\end{array}$ \\
\hline \multicolumn{10}{|l|}{ Pakistan } \\
\hline Overall & 13.81 & 17.26 & $-25.5^{*}$ & 2.36 & 3.35 & $-7.62 *$ & 0.62 & 0.97 & $-2.91 *$ \\
\hline Rural & 10.27 & 12.93 & $-16.0 *$ & 1.59 & 2.19 & $-4.54 *$ & 0.38 & 0.55 & $-3.36 *$ \\
\hline Urban & 23.08 & 27.01 & $-23.5^{*}$ & 4.39 & 5.96 & $-5.88 *$ & 1.24 & 1.94 & $-6.62 *$ \\
\hline \multicolumn{10}{|l|}{ Rural } \\
\hline Punjab & 12.57 & 14.23 & $-13.6^{*}$ & 2.02 & 2.43 & $-2.15^{*}$ & 0.51 & 0.6 & -1.40 \\
\hline Sind & 5.92 & 9.47 & $-5.05^{*}$ & 0.75 & 1.58 & $-3.31 *$ & 0.15 & 0.48 & $-3.04 *$ \\
\hline NWFP & 8.47 & 13.95 & $-4.84 *$ & 1.19 & 2.27 & $-3.26 *$ & 0.27 & 0.52 & $-2.64 *$ \\
\hline Balochistan & 2.36 & 1.62 & $-2.77^{*}$ & 0.37 & 0.38 & -0.05 & 0.09 & 0.11 & -0.32 \\
\hline \multicolumn{10}{|l|}{ Urban } \\
\hline Punjab & 20.5 & 21.52 & $-15.3^{*}$ & 3.89 & 4.39 & -1.46 & 1.1 & 1.37 & $-1.8^{*}$ \\
\hline Sind & 28.12 & 36.23 & $-14.5^{*}$ & 5.6 & 8.88 & $-5.79 *$ & 1.6 & 3.05 & $-5.81 *$ \\
\hline NWFP & 21.19 & 27.92 & $-7.98 *$ & 3.25 & 4.68 & $-2.59 *$ & 0.77 & 1.18 & $-2.23 *$ \\
\hline Balochistan & 12.01 & 11.13 & $-4.73 *$ & 1.31 & 1.58 & -0.61 & 0.25 & 0.38 & -0.87 \\
\hline \multicolumn{10}{|l|}{ Overall } \\
\hline Punjab & 13.9 & 16.01 & $18.6^{*}$ & 2.29 & 2.71 & $-2.61 *$ & 0.59 & 0.72 & $-2.20 *$ \\
\hline Sind & 12.39 & 14.87 & $12.2^{*}$ & 1.68 & 2.54 & $-3.94 *$ & 0.37 & 0.73 & $-4.01 *$ \\
\hline NWFP & 10.82 & 16.64 & $-7.66^{*}$ & 13.87 & 2.52 & $-4.31 *$ & 0.32 & 0.58 & $-3.31 *$ \\
\hline Balochistan & 5.72 & 4.72 & $-5.33 *$ & 0.97 & 0.79 & 0.77 & 0.25 & 0.23 & 0.22 \\
\hline
\end{tabular}

Source: Author's calculation based on micro data of Household Income and Expenditure Survey (HIES), Federal Bureau of Statistics [Government of Pakistan (1987-88, 1990-91)] 
during the period of structural adjustment. The results indicate that incidence of poverty increased from 13.81 percent to 17.26 percent between 1987-88 and 1990$91 .^{12}$ It is noteworthy that not only changes in poverty incidence but also changes in intensity and severity were more pronounced in urban than in rural areas. ${ }^{13}$ However, these conclusions are based on the chosen poverty line and measure. It may be possible that different poverty lines and measures may produce different results about poverty levels. ${ }^{14}$ In this situation, it would be prudent to see how sensitive these results are to the choice of the poverty line and measure. To answer the question, the robustness of results to alternative poverty lines and poverty measures is examined by applying the stochastic dominance conditions. ${ }^{15}$

${ }^{12}$ The Consumer Price Index and Sensitive Price Indicator rose 32 percent and 35 percent between 1987-88 and 1990-91. However, the changes are not very different in the above indices. Since Sensitive price indicator reflects the consumption pattern of poor, the poverty lines for 1987-88 are adjusted to 1990-91 prices by the Sensitive price indicator for inflation. It has been argued that poverty lines should be consistent with the consumption pattern of the reference community. Hence, provinceregion specific poverty lines have been used to estimate the changes in poverty across regions and provinces.

${ }^{13}$ To test the statistical significance of observed changes in poverty measures, the Kakwani (1990) test-statistics for the three FGT poverty measures are also given in Table 2. The test-statistics for poverty differences between 1987-88 and 1990-91 are significant at 5 percent level of significance. Thus, the observed increase in poverty is not due to a sampling error.

${ }^{14}$ The empirical evidence on poverty assessment suggests that different authors employing different methods and choosing different arbitrary poverty lines reported divergent poverty trends for Pakistan over the last quarter century, for example see Naseem (1973); Mujahid (1978) and Amjad and Irfan (1984). This reflects that there is pervasive uncertainty due to the arbitrary decisions taken in poverty measurement which give rise to problems and create difficulties in making judgements for poverty comparison. A recent strand of research showed that such difficulties may be avoided by the use of results given by the stochastic dominance theory. See Atkinson (1987).

${ }^{15}$ Atkinson (1987) devised an explicit procedure based on stochastic dominance conditions. The restricted form of first order stochastic dominance condition is:

For there to be for all $\mathrm{Z} \in\left[\mathrm{Z}^{-}, \mathrm{Z}^{+}\right]$a reduction, or no increase in poverty as measured by the headcount, on moving from the distribution $F^{1}$ to $F$ :

$$
\left[F(Z)-F^{1}(Z)\right]<0 \text { for all } Z \in\left[Z^{-}, Z^{+}\right]
$$

where $F$ and $F^{1}$ are two income or expenditure distributions, and $Z \in\left[Z^{-}, Z^{+}\right]$is the range of the admissible poverty lines.

The above condition states that if the cumulative distribution (expenditure or income) $F^{1}$ lies nowhere above (and at least somewhere below) that for $F$ all points up to admissible poverty line, then all well-behaved poverty measures will indicate a lower poverty in $F^{1}$ than $F$ distribution.

The global form of the first order dominance condition is

$$
\left[F(Z)-F^{1}(Z)\right]<0 \text { for all } Z
$$

The global form the above condition states that if $F$ is everywhere above that for $F^{1}$. Poverty is higher in $F$ than in $F^{1}$ distribution, no matter what the poverty line or measure.

The global first order condition for stochastic dominance also implies global second order stochastic dominance. This condition is equivalent to the poverty deficit being everywhere not higher in 1987-88 than 1990-91. These dominance conditions can also be applied in the Pen's parade diagram which is drawn slightly different from the cumulative frequency distribution. The former can be drawn from the latter simply by interchanging the axes of cumulative frequency distribution. 
Figure 1 presents the Pen's parade ${ }^{16}$ of consumption expenditure of Pakistan at 1990-91 prices. The 1990-91 distribution lies entirely below the 1987-88 distribution. Thus, the global first order dominance condition holds and it can be concluded that all well-behaved poverty measures and all poverty lines will indicate an unambiguous increase in poverty over the period. ${ }^{17}$

Thus, it appears that changes in absolute poverty are consistent with the stylised facts of structural adjustment programmes over the period. In the previous sections, three macroeconomic indicators suggest a decline in the welfare and living conditions of the poor segments of the population; (a) decline in the real wages; (b) decline in the real private per capita consumption and (c) an increase in the unemployment rate during the period. These results seem to be the outcome of government's wage and employment restraint policies which have been followed as a result of the conditionalities attached to the loans advanced by the IMF under the structural adjustment programme over the period. This suggests that structural adjustment seems to have adverse effects on the vulnerable groups of the population. Absolute poverty increased over the period of adjustment. Since wage employment is more common in urban areas than in rural areas, absolute poverty in Pakistan has become much more of an urban problem than before. Sindh is more urbanised than other provinces. Hence, it has been seriously affected by the increases in absolute poverty during the period of adjustment. On the other hand, increases in support prices of agricultural commodities, together with higher production seem to have had a positive effect on the real earnings of net producers of these commodities but a negative effect on net consumers of these commodities. Hence, increase in absolute poverty was less pronounced in rural than the urban areas.

However, the above relationship between structural adjustment and poverty is at best suggestive and do not establish, causal relationships. To explain differing records of growth and poverty, one needs to specify the mechanisms and processes that show how economic growth and poverty are in turn affected by some set of explanatory factors. The above approach provides broad perspectives and useful insights on the determinants of poverty but not empirical estimates of the impact of specific policies.

\section{CONCLUDING REMARKS AND POLICY IMPLICATIONS}

The paper suggests that changes in absolute poverty are consistent with the stylised effects of the structural adjustment policies over the period. The experience

\footnotetext{
${ }^{16}$ Pen's parade is a procession in which marchers are lined up in order of height (according to income or expenditure) from the shortest to the tallest. See Pen (1971).

${ }^{17}$ Similarly, the stochastic dominance conditions are derived to draw an unambiguous conclusion for each region and province to derive an unambiguous conclusion. See Anwar (1996).
} 
Figure 1: Pen's Parade for Pakistan,1987-88 and 1990-91

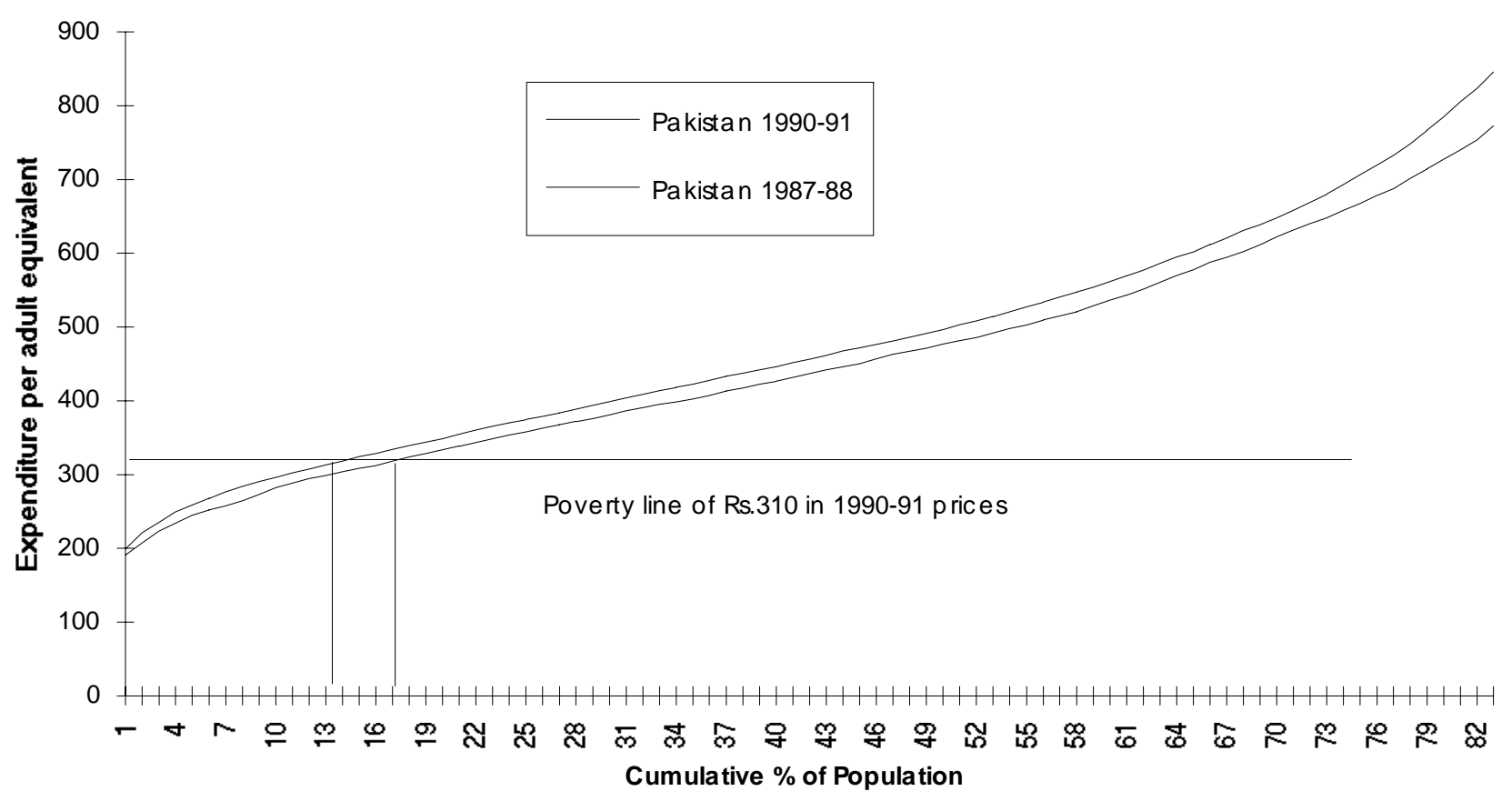


of Pakistan's structural adjustment programme and a subsequent decline in the living standard of the poor highlights concerns voiced previously by critics of the structural adjustment programme within the framework of IMF/World Bank. Some policy implications are discussed which are important for designing future adjustment programme in Pakistan.

Excessive reliance on demand management in scale or speed is counterproductive for adjustment. Adjustment strategies need to account for the trade-off between short-term gains and long-term benefits foregone. Policy-maker should seek to ameliorate the most distressing cost arising in the short run. The extent and speed of stabilisation can be debated. The more gradual approach will cause less sacrifice of social and economic infrastructure and allow more time for resource switching.

Greater emphasis should be placed on achieving fiscal balance through increases in revenue from consumption, income and wealth taxes so as to avoid excessive expenditure cut. Salary structure of public sector needs to be reviewed with a view to maintain the positive growth of wages among low and middle income employees particularly for Clerical workers, so as to avoid the intensity and severity of poverty among the urban households. There is a need for increasing rates of return to labour (primary asset of the urban poor) through better functioning of the labour market during the period of adjustment.

The final policy implication concern targeting of assistance to the poor and alleviation of the immediate adjustment cost. In contrast to universal food subsidies, targeted subsidies as a short term policy measure not only offset the real income losses caused by higher prices but also greatly reduce the economic costs in the fiscal budget.

\section{REFERENCES}

Amjad, R., and M. Irfan (1984) Poverty in Rural Pakistan. In ILO-ARTEP (eds) Impact of Return Migration on Domestic Employment in Pakistan: A Preliminary Analysis. New Delhi: ILO, Asian Regional Team for Employment Programme.

Anwar, T. (1992) Growth and Human Development. A Cross-country Analysis with Particular Reference to Pakistan, M.Sc. (Quantitative Development Economics) dissertation submitted to the University of Warwick, Coventry, UK.

Anwar, T. (1996) Changes in Poverty and Inequality in Pakistan during the Period of Structural Adjustment, Ph.D. Thesis submitted to the University of Sussex, UK.

Atkinson, A. B (1987) On the Measurement of Poverty. Econometrica 55:4 749-764.

Bilquees, F. (1992) Trends in Intersectoral Wages in Pakistan. The Pakistan Development Review 31:4.

Demery, L., and T. Addison (1993) The Impact of Macroeconomic Adjustment on Poverty in the Presence of Wage Rigidities. Journal of Development Economics 40:2 April. 
Foster, James, J. Greer and E. Thorbecke (1984) A Class of Decomposable Poverty Measures. Econometrica 52: 761-765

IMF (1986) Fund-supported Adjustment Programmes, Fiscal Policy and Income Distribution. Washington, D. C.: IMF. (Occasional Paper No. 46.)

Kakwani, Nanak (1990) Testing for Significance of Poverty Differences with Application to Cote d Ivoire. Washington, D. C.: The World Bank. (LSMS Working Paper No. 62.)

Kanbur, R. (1987) Structural Adjustment, Macroeconomic Adjustment and Poverty: A Methodology for Analysis. World Development 15:2.

Kemal, A. R. (1992) Fiscal and Monetary Policies and Employment in Pakistan. Journal of the Institute of Bankers in Pakistan 58:4.

Kemal, A. R. (1993) Retrenchment Policy and Labour Shedding in Pakistan. Geneva: ILO. (Occasional Paper No. 17.)

Mujahid, G. B. (1978) A Note on Measurement of Poverty and Income Inequalities in Pakistan: Some Observations of Methodology. The Pakistan Development Review 17:3 365-377.

Naseem, S. M. (1973) Mass Poverty in Pakistan: Some Preliminary Findings. The Pakistan Development Review 12:4 312-360.

Pakistan, Government of (1992) Economic Reforms, November 1990-January, 1992, Islamabad: Ministry of Finance and Economic Affairs.

Pakistan, Government of (1993) Economic Survey. Islamabad: Ministry of Finance, and Various Issues from 1987 to 1993.

Pakistan, Government of (Various Issues) Household Income and Expenditure Survey (HIES), 1987-88 and 199-91. Micro Data Tape. Islamabad: Federal Bureau of Statistics, Statistics Division.

Pen, J. (1971) Income Distribution. Harmondsworth: Penguin.

World Bank (1990) Making Adjustment Work for the Poor, A Framework for Policy Reform in Africa. Washington, D. C: The World Bank.

Zaidi, Akbar (1994) The Structural Adjustment Programme and Pakistan: External Influence or Acquiescence. Pakistan Journal of Applied Economics 10:1\&2 2146. 


\section{Comments}

This is an important and interesting paper in the sense that it deals with the most neglected area of research in Pakistan. Recently, structural adjustment and its social effects have become a sensitive issue not only for the foreign donor agencies but also for the recipient countries.

In this paper, the author has obtained interesting results that various structural adjustment policies such as expenditure reducing measures, revenue raising measures, foreign trade policies, and pricing policies have increased poverty during the period of adjustment in Pakistan. Keeping in view the vast and controversial debate about the economic and social effects of various structural adjustment programs, I have a number of observations on this paper.

The author has used three alternative measures of poverty i.e., Head-count Ratio, Poverty Gap, and FGT Measure. In his paper, the author did not provide any justification for this methodology over other competing methodologies. Recently, computable general equilibrium (CGE) models developed by Taylor (1990), Thorbecke (1991), Demery and Demery (1991), Morrison (1991), Branson and Melo (1992), among others, have become the most common methodology to evaluate the social effects of various adjustment policies on poverty, income distribution, and employment in developing countries. CGE modelling not only provide overall effects of structural adjustment programmes but also the effects of individual adjustment policies can be obtained, which is not possible under the poverty measures used by the author. In this study, the author even did not refer that such models exist.

The author claims that poverty has increased during the adjustment period. Is an increase in poverty only because of adjustment policies or some other factors are also involved? No explanation is given for other factors. Actually, such poverty measures ignore other important economic and political factors in the analysis.

Summary of Table of the results (Appendix I) does not provide a clear cut answer whether poverty has increased during the adjustment period. For example, poverty differences during 1987-88 and 1990-91 are significant in Rural Punjab under the first two methods ( $\mathrm{P}_{0}$ and $\mathrm{P}_{1}$ methods) while they are insignificant under the third method $\left(\mathrm{P}_{2}\right)$. The same is the case with rural, urban, and overall Baluchistan and urban Punjab, that is, poverty differences are significant under one methodology while insignificant under the other methodology for the same period.

Finally, the author should compare poverty estimates with other studies in Pakistan. For example, Malik (1992) reported estimates of poverty using the same three measures for the period 1987-88 and obtained different results.

Pakistan Institute of

Zafar Iqbal

Development Economics,

Islamabad. 